Education Sciences

ISSN: $13087274 \quad$ (NWSAES)

ID: $2015.10 .4 .1 C 0645$

Status : Original Study

Received: April 2015

Accepted: October 2015

Nilüfer Şeker Sır

Yıldız Teknik University, sekernil@gmail.com, İstanbul-Turkey

\title{
Hakan Karataş
}

Yıldız Teknik University, hkaratas@yildiz.edu.tr, Ístanbul-Turkey

Nadir Çeliköz

Yıldız Teknik University, ncelikoz@gmail.com, İstanbul-Turkey

http://dx.doi.org/10.12739/NWSA.2015.10.4.1C0645

\section{ÖĞRETMEN ADAYLARININ ÖĞRENME STİLI TERCİHLERİNE İL̇ŞKİN BİR İNCELEME}

\section{Öz}

Bu çalışma, Müzik, Matematik, Türkçe, Beden Eğitimi ve Fen Bilgisi öğretmen adaylarının baskın öğrenme stillerinin ne olduğunu, öğrenme stillerinin eğitim görülen alan, cinsiyet ve sınıf düzeyi bağlamında değişiklik gösterip göstermediğini 590 kişiden oluşan bir örneklem ile belirlemeyi amaçlayan betimsel nitelikli araştırma sunumu içermektedir. Araştırma verilerinin toplanmasında 44 maddeden oluşan ve Seval Fer(2003) tarafından Türkçe'ye uyarlanan Felder ve Silverman (1996) tarafından geliştirilen Öğrenme Stili Envanteri kullanılmış, bağımsız değişkenler olarak envantere cinsiyet, bölüm ve sınıf bilgileri eklenmiştir. Toplanan verilerin analizi için cinsiyet değişkenine ilişkin ikili karşılaştırmalarda t-testi, bölüm ve sınıf değişkenlerine ilişkin çoklu karşılaştırmalarda ise tek yönlü (ANOVA) kullanılmıştır. Araştırma sonucunda katılımcıların yansıtan, duyumsal, görsel ve bütünsel öğrenme stillerinde yoğunlaştıkları, cinsiyetin öğrenme stillerinin sadece duyumsal/sezgisel boyutunu anlamlı olarak etkilediği, diğer boyutlar üzerinde etkisinin olmadığı, bölüm değişkeninin tüm boyutlarda öğrenme stili tercihini etkilediği, sınıf düzeyi değişkeninin ise sadece aktif/yansıtan ve görsel/sözel boyuta ait puanlar üzerinde etkisinin olduğu tespit edilmiştir.

Anahtar Kelimeler: Öğretmen Adayları, Öğrenme Stili, Cinsiyet, Bölüm, Sınıf Değişkenleri

\section{AN INVESTIGATION ON THE LEARNING STYLE PREFERENCES OF PRE-SERVICE TEACHERS'}

\section{ABSTRACT}

This study aims to present a descriptive research on the learning style preferences of pre-service teachers and it seeks whether learning style preference of the participants depend on their gender, department or grade level. The study was carried out in the departments of Turkish, Science, Music, Mathematics and Physical Education containing 590 participants. Data were collected through a 44 item learning style questionnaire which was developed by Felder \& Silverman (1996) and adapted to Turkish by Seval Fer (2003). For data analysis, independent t-test in terms of gender and relating to department and grade ANOVA were used in order to compare the means of the groups. According to the results of the study, it was found that general learning style preferences of the participants were reflective, sensing, visual and global. The results show that gender affects the participants' score of sensing/intuitive dimension only. Department variable has a significant effect on the learning style preferences whereas grade level is found to be influential only on active/reflective and visual/verbal dimensions.

Keywords: Pre-Service Teachers, Learning Style, Gender, Department, Grade Variables 
Şeker Sır, N., Karataş, H. ve Celiköz, N. Education Sciences (NWSAES), 1C0645, 2015; 10(4): 237-252.

\section{GIRIŞ (INTRODUCTION)}

Bireylerin söz konusu olduğu bütün uğraşıların temelinde bireyi tanıma süreci yer almaktadır. Bireyi tanımak, onun kimliği ve görünüşüne ilişkin özellikleri yanında daha çok onun biyolojik, psikolojik ve sosyolojik nitelikteki davranışlarını, kişisel özelliklerini ve gereksinimlerini bilmeyi gerektirmektedir. Her bireyin kendine özgü anlama, algılama ve olaylara yaklaşım tarzı vardır. Bireyin tanınması için, bireylerin ilgi ve yetenekleri, başarı ve başarısızlıkları, kişisel ve sosyal uyum düzeyleri, sorunları, zayıf ve güçlü yanları, ilgi, tavır ve değer yargıları, yetiştiği çevrenin geliştirici ve engelleyici etkileri gibi ve daha pek çok özelliklerinin ayrıntılı olarak bilinmesi gerekir (Ömeroğlu, 2008).

Eğitim, bireyler arasındaki farklılıklara duyarlı olabildiği ölçüde başarılı olabilir. Eğitimde bireysel farklılıkların ön plana çıkarılarak; eğitim-öğretim etkinliklerinin bireysel farklılıklara göre yapılması öğrenci başarısını arttıracaktır (Aktepe, 2005). Bütün öğrencilerin aynı özelliklere sahip olduğunu varsaymak, öğrencinin kendi zekâsını veya yeteneğini ortaya çıkarması açısından büyük sorunları beraberinde getirmektedir. Bu yönden problemleri, üstün yönleri, zayıflıkları, başarı ve başarısızlıklarıyla her öğrencinin ayrı bir dünya olduğunu bilmek ve bunları keşfetmeye çalışmak gerekir. Oluşturulacak zengin bir öğrenme-öğretme ortamında bireylerin öğrenme kapasitesini arttırmak mümkün olacağı gibi bireylerin bu farklılıkların aslında yaşamda bir birey olarak aslında ne kadar gerekli ve önemli olduğu bilinci de bireye kazandırılmalıdır.

Her bireyin dünyayı anlamak için kullandığı öznel bir bilgi kapasitesine, düşüncelere ve deneyimlere sahip olduğu ve tüm bu özelliklerin de öğrenme sürecinde etkili olabileceği düşünüldüğünde, öğrenmede bireysel farklılıkların varlığını kabul etmek kaçınılmazdır. Bireylerin yaşı, cinsiyeti, fiziksel özellikleri, zekâsı, ilgileri, yetenekleri ve diğer birçok özelliği onların öğrenme sürecini etkilemektedir. Öğrencilerin eğitim ve öğretim ortamındaki farklılıklarının saptanmasında takip edilen yöntemlerden biri de öğrenme stillerinin belirlenmesidir. Okullardaki eğitim süreci merkeze alındığında, öğrencilerin "öğrenme stilleri", hem kendi kendilerine öğrenmelerini hem de öğretmenler tarafından istendik davranışların kendilerine öğretilmesi sürecini etkileyen en önemli özelliklerinden biri olduğu söylenebilir (Bahar ve Bilgin, 2008).

Günümüzde eğitimle ilgili çalışmalarda öğrenmenin tüm öğrenciler için kolay, verimli ve uygun duruma getirilmesi amaçlanmaktadır (Demir, 2008). Demir (2008)'e göre, bu amaca ulaşmak için her bir öğrencinin öğrenme stilinin bilinmesi ve buna uygun olarak, gelişen ve değişen teknolojinin de yardımıyla, öğrenme-öğretme faaliyetlerinde yeni yaklaşımları ve çağdaş öğretim yöntemlerini uygulamak gerekmektedir. Zira öğrencilerin sahip oldukları kişisel özellikler belirlenebilirse onlar için en uygun öğrenme şekli de ortaya çıkarılır (Güven ve Özbek, 2007). Ayrıca, öğretim sürecinde öğrenme stillerinin kullanımının eğitim kalitesini geliştirmede önemli bir faktör olduğunu gösteren birçok çalışma bulunmaktadır (Felder and Spurlin, 2005; Hawk and Shah, 2007).

Öğrenme stillerinin öğrencilerin öğrenme ve öğretmenlerin öğretim süreçleri üzerinde önemli bir faktör olduğu gerçeğinden yola çıkıldığında öğretmen ve öğretmen adaylarının da öğrenme stilleri konusunda farkındalıklarının gelişmiş olması büyük önem taşımaktadır. Bireylerin öğrenme stilini değerlendirmek, öğretme ve öğrenme süreci için önem taşımaktadır (Hein ve Budny, 2000). Öğrencilerin öğrenme stillerinin bilinmesi öğrenciler için düzenlenecek öğrenme ve öğretme ortamlarında kullanılacak olan yöntem, teknik ve ekinliklerin geliştirilmesinde öğretmenlere yardımcı olacaktır. Bireylerin öğrenme 
Sheker Sır, N., Karataş, H. ve Çeliköz, N. Education Sciences (NWSAES), 1C0645, 2015; 10(4): 237-252.

stilleri belirlenirse, bireylerin nasıl öğrendiği ve nasıl bir öğretim tasarımı uygulanması gerektiği daha kolay bir şekilde anlaşılabilir. Böylece öğretmen öncelikle kendisi için, sonra da buna uygun öğretim ortamları oluşturabilir (Babadoğan, 2000). Öğrenme stillerinin öğrenci başarısı üzerinde etkili olduğunu gösteren pek çok araştırma bulunmaktadır (Collison, 2000; Scales, 2000; Uzuntiryaki, Bilgin ve Geban, 2002; Kılıç, 2002; Bilgin ve Durmuş, 2003; Peker, 2003; Arslan ve Babadoğan, 2005; Bahar, Özen ve Gülaçtı, 2007).

\section{2. ÇALIŞMANIN ÖNEMI (RESEARCH SIGNIFICANCE)}

Çağdaş eğitim yaklaşımlarının üzerinde durduğu en önemli konulardan biri eğitsel uygulamaların öğrenenlerin kişisel özelliklerine duyarlı olarak gerçekleştirilmesidir (Genç ve Kocaarslan, 2013). Günümüzde eğitimin hemen hemen her alanında geleneksel öğretim yöntemlerinin yerini 'öğrenci merkezli' öğretim yöntemlerine bırakması, yani öğrenimin gittikçe bireyselleşmesi, öğrencinin bireysel özelliklerini ve onların öğrenme tercihlerini hakkında bilgi sahibi olmayı gerekli kılmaktadır (Sünbül ve Yağışan, 2009). Bu nedenle literatürde öğrencilerin öğrenme sitillerini belirlemeye ya da açıklamaya çalışan birçok modele rastlamak mümkündür. Ancak bunlar arasında en çok kabul görenler; (1) Keefe, (2) Felder ve Silverman, (3) Kolb, (4) Gregorc ve (5) Dunn \& Dunn tarafından geliştirilen öğrenme stilleri modelleridir.

Deniz (2011)'e göre kişinin bilgiyi alma ve işleme süreçlerinde izlemeyi tercih ettiği yol olan öğrenme stillerinin bilinmesi, öğrenme ortamlarının düzenlenmesi açısından büyük önem taşımaktadır (akt. Yetim, 2009). Bahar (2011), öğrenme stilini, "Öğrenenlerin nasıl algıladıkları, öğrenme ortamıyla nasıl etkileşimde oldukları, öğrenme ortamına yönelik verilen tepkilerin az çok kalıcı göstergeleri olan bilişsel, duyuşsal ve fizyolojik davranışlar" olarak tanımlanmaktadır (akt. Given, B.K., 1996). Zengin ve Alşahan (2010)'un aktardığına göre, öğrenme ortamları, öğretim kaynakları ve öğretim yaklaşımları öğrenme stillerine uygun olarak hazırlandığında, öğrencilerin başarıları istatistiksel olarak artmaktadır (akt. Yenice ve Saracaloğlu, 2009).

Felder (1996), bilgiyi alma ve işleme sürecinde, öğrencilerin tercih ettikleri karakteristik bir takım yöntemler olduğunu belirterek, kimi öğrenciler veriler ve işlemler üzerinde odaklanırken, kimilerinin kuramlar ve matematiksel modellerde daha rahat olduklarını, bir kısım öğrencilerin şemalar, resimler ve grafikler gibi bilginin görsel formlarına, bir kısmının da yazılı ve sözlü açıklamalara daha güçlü tepki verdiklerini, bunlar gibi bir grup öğrencinin etkin ve etkileşimli öğrenmeyi tercih ettiklerini, bir başka grubun ise daha içsel ve bireysel yöntemleri tercih ettiğini ifade etmektedir. Bu farklılıklar, farklı öğrenme stillerine sahip olmanın bir göstergesidir.

Gerek öğrenme stilleri gerekse öğrenme stratejileri kavramı bireyin öğrenme sürecinde hangi yollarla bilgiyi aldığına, işlediğine ve hatırladığına dikkat çekmektedir. Birey kendi öğrenme stilini bildiğinde daha kolay ve çabuk öğrenebilecek; karşılaştığı problemlerde daha hızlı çözüm üretebilecek; kendine güven duygusu artacak, kaygı düzeyi azalacak; derslere ve okula karşı olumlu tutum geliştirebilecektir (Biggs 2001:81; Entwistle, McCune ve Walker 2001:129). Öğrenme stili modellerinin çeşitlilik göstermesi, öğrencilerin öğrenme sitillerini belirleme yol, yöntem ve araçlarını farklılaştırdığı gibi bu kavramının tanımlanmasında dahi güçlüklere yol açmaktadır. Literatürde birbiriyle tutarlı olmayan birçok tanımının yer aldığı, dikkate alındığında öğrenme stili genel olarak; öğrenme sürecini etkili ve verimli kılmak için öğrenenlerin öğrenme 
Şeker Sır, N., Karataş, H. ve Celiköz, N. Education Sciences (NWSAES), 1C0645, 2015; 10(4): 237-252.

ortamlarıyla etkileşimde bulunması ve uyarıcıları algılama, kodlama, hatırlama ve kontrol etme süreçlerini kendine özgü bir hale dönüştürerek kullanması olarak tanımlanabilir. Şimşek (2001)'e göre öğrenme stili içerisinde; (1) algısal tercihler ve güçlükler, (2) motivasyonel farklılıklar, (3) psikolojik faktörler ve (4) bilgiyi işleme alışkanlıkları önemli değişkenler olarak yer almaktadır. Öğrenme stilini bireyin, "bilgiyi alma ve işleme süreçlerinde izlemeyi tercih ettiği yol" olarak tanımlayan Deniz (2011), öğrencilerin öğrenme stillerinin bilinmesinin, öğrenme ortamlarının düzenlenmesi açısından büyük önem taşıdığını vurgulamaktadır. Zengin ve Alşahan (2010)'a göre, öğrenme ortamları, öğretim kaynakları ve öğretim yaklaşımları öğrenme stillerine uygun olarak hazırlandığında, öğrencilerin başarıları istatistiksel olarak artmaktadır (Akt. Yenice ve Saracaloğlu, 2009).

Öğrenme stilleriyle ilgili çalışmaların temelinde, bireysel farklılıkların öğrenme ortamında bir zenginlik olduğu düşüncesi yatmaktadır (Demir, 2008). Nitekim son yıllarda eğitim alanında yapılmakta olan bilimsel çalışmaların büyük çoğunluğu, öğrenenlerin bireysel farklılıklarına göre öğrenme yollarını zenginleştirme ve onların öğrenme ortamlarını daha etkili biçimde geliştirme amacı taşımaktadır (Genç ve Kocaarslan, 2013). Öğrencilere ait bireysel farklılıkların hangilerinin öğrenme stilleri üzerinde etkili olduğu üzerine birçok araştırma yapılmasına karşın elde edilen sonuçlar farklılık arz etmektedir.

Köse (2010), Fen Bilgisi öğretmen adaylarının öğrenme stilleri arasındaki ilişkiyi incelemek amacıyla hazırladığı yüksek lisans tezinde, öğrencilerin genel olarak tercih ettikleri öğrenme stilinin ayrıştırma olduğunu, öğrenme stilinin sınıf düzeyi ile ilişkili olduğunu ancak cinsiyet ile ilişkili olmadığını tespit etmiştir. Deniz ve arkadaşları (2008), İlköğretim Matematik, Fen Bilgisi ve Türkçe öğretmeni adayları üzerinde yaptıkları incelemede, Fen Bilgisi ve Türkçe öğretmeni adaylarının genel öğrenme stillerinin özümseme, Matematik öğretmeni adaylarının genel öğrenme stillerinin ise ayrıştırma olduğunu, cinsiyetin öğrenme stilleri üzerinde etkisinin olmadığını, buna karşın sınıf düzeyinin ve bölümler arası farklılığın öğrenme stilleri üzerinde etkisi olduğunu aktarmaktadır. Sünbül ve Yağışan (2009)'un güzel sanatlar bölümünde okuyan öğrenciler üzerinde Vark Öğrenme Tercihleri Envanterini kullanarak yaptığı çalışmada da benzer şekilde, bölümler arası farklılığın ve sınıf düzeylerinin öğrencilerin öğrenme stillerini etkilediği, cinsiyetin ise bir etkisinin bulunmadığı belirtilmektedir.

Gürsoy (2008), Sınıf Öğretmenliği, Fen Bilgisi Öğretmenliği ve Türkçe Öğretmenliği bölümlerinde eğitim gören 1. ve 4. sınıf öğrencilerinin öğrenme stillerini çeşitli değişkenlere göre incelediği yüksek lisans tezinde, farklı bölümlerde ve farklı sınıflarda okuyan öğrencilerin farklı öğrenme stillerine sahip olduklarını, ayrıca cinsiyetin öğrenme stilini belirlemede bir etki yaratmadığı ifade etmektedir. Çöğenli (2011)'in Sınıf Öğretmeni adayları, Bahar (2011)'in Fen Bilgisi Öğretmeni adayları, Demir (2008)'in ise Türkçe Öğretmeni adayları üzerinde yaptığı çalışmalarda, cinsiyetin öğrenme stilleri üzerinde anlamlı bir etkisinin olmadığını belirlenmiştir. Bahar, Gülaçtı ve Özen (2009), Eğitim Fakültesi'nde okuyan öğrenciler arasında gözlenen baskın öğrenme stilinin ayrışma olduğunu ve öğrenme stillerinin cinsiyete ve kayıtlı olunan programa göre farklı olmadığını aktarmaktadır. Alaçayır (2011), Grasha-Reichman öğrenme stili ölçeğini kullandığı yüksek lisans tezinde, Zihinsel Engelliler Öğretmenliği 4. sınıfta okuyan öğrencilerin öğrenme stillerinin cinsiyete göre değişmediğini ancak mezun oldukları okul türüne göre farklılaştı̆̆ını tespit etmiştir. 
Sheker Sır, N., Karataş, H. ve Çeliköz, N. Education Sciences (NWSAES), 1C0645, 2015; 10(4):237-252.

\begin{abstract}
Çalışmalarında Kolb öğrenme stilleri envanterini kullanan bazı araştırmacıların ise yukarıdaki sonuçlardan farklı bulgulara ulaştıkları görülmektedir. Koç (2010), Marmara Bölgesindeki Beden Eğitimi ve Spor Yüksek Okulu'nda okuyan öğrencilerin öğrenme stillerini çeşitli değişkenlere göre incelediği yüksek lisans tezinde, öğrencilerin genelinin özümseyici öğrenme stiline sahip olduğunu, öğrenme stillerinin cinsiyete göre farklılaştığını, alt bölümler ve sınıflar arası düzey farkının öğrenme stiline etkisinin olmadığını aktarmaktadır. Benzer şekilde, Çiğdem (2010), Sınıf Öğretmeni adayları öğrenme stilleri üzerinde yürüttüğü yüksek lisans çalışmasında, cinsiyetin öğrenme stilleri üzerinde anlamlı fark yarattığını
\end{abstract} belirlemiştir.

Erişti ve Yalız (2010)'un Beden Eğitimi ve Spor Okulu öğrencileri ve Deniz (2011)'in müzik öğretmen adayları üzerinde yaptıkları çalışmalarda, öğrencilerin genel olarak özümseyici öğrenme stiline sahip olduğu ve sınıf düzeylerinin öğrenme stilleri üzerinde etkisinin olmadığı belirtilmektedir. Aynı şekilde, Genç ve Kocaarslan (2013)'ün Fen Bilgisi, Sosyal Bilgiler ve Sınıf Öğretmenliği adayları, Alşahan ve Zengin (2010)'un ise bu bölümlerde okuyanlara ilave olarak Matematik ve Okul Öncesi Öğretmenliğinde okuyan öğrenciler üzerinde yaptıkları çalışmalarda farklı bölümlerdeki öğrencilerin öğrenme stillerinin anlamlı farklılık göstermediği sonucuna ulaşılmıştır.

Keleş (2009), Grasha-Reichman öğrenme stili ölçeğini kullandığı yüksek lisans tezinde, Sınıf Öğretmenliği ve İngilizce Öğretmenliği adayları ile felsefe ve psikolojik danışmanlık bölümlerinde okuyan öğrencilerin öğrenme stillerinin cinsiyete göre farklılaştığını belirtmektedir. Köprülü (2004), Felder ve Silverman (1996) tarafından geliştirilen Öğrenme Stilleri Envanterini kullandığı doktora tezinde, 1. ve 4. sınıfta okuyan İngilizce Öğretmeni adaylarının cinsiyetlerinin öğrenme stilleri üzerinde etkili olduğunu ve farklı sınıf düzeylerinde okuyan öğrencilerin farklı öğrenme stillerine sahip olduklarını bildirmektedir. De Shields (2005), "Productivity Environmental Preference Survey" (PEPS) (Dunn \& Price, 1996) kullanarak hemşire ve öğretmen adayları üzerinde hazırladığı doktora tezinde, farklı bölümlerde okuyan öğrencilerin öğrenme stillerinin de farklı olduğunu, farklı cinsiyetteki ve sınıf düzeyindeki öğrencilerin farklı öğrenme stillerine sahip olduğunu tespit etmiştir. Sywelem ve Dahawy (2010)'un "Perceptual Modality Preference Survey" (PMPS) kullanarak Eğitim Fakültesi öğrencileri üzerinde yaptığı incelemede, bölümler arası farklılıkların, cinsiyetin ve sınıf düzeylerinin öğrenme stillerini anlamlı derecede etkilediği sonucuna ulaşılmıştır. Tseng (2001) İngilizce eğitimi gören Tayvan'lı öğrenciler üzerinde gerçekleştirdiği ve "Perceptual Learning style Preference Questionnaire" kullandığı çalışmasında benzer şekilde, öğrencilerin cinsiyetinin öğrenme stillerini değiştirdiği sonucuna varmıştır.

Öğrencilerin bireysel farklılıklarının öğrenme stillerine olan etkisinin incelendiği çalışmalarda birbiri ile çelişen sonuçlar ortaya çıkmasına karşın, tespitlerin genelinde öğrencilerin bölümleri arasındaki farkların, cinsiyetin ve sınıf düzeylerinin öğrenme stilleri üzerinde etkili olduğu sonucuna ulaşıldığı görülmektedir. Bu araştırmanın amacı; Müzik, Matematik, Türkçe, Beden Eğitimi ve Fen Bilgisi öğretmen adaylarının baskın öğrenme stillerini tespit etmek, bununla birlikte, öğrenme stillerinin eğitim görülen alan, cinsiyet ve sınıf düzeyi bağlamında değişiklik gösterip göstermediğini incelemektir. Bu araştırmada Felder ve Silverman (1996) (Felder, 1996) tarafından geliştirilen ve Fer (2003) tarafından geçerlik ve güvenirlik çalışması yapılarak Türkçe'ye uyarlanan dört boyutlu Öğrenme stili Envanteri kullanılmıştır. Bu boyutlar aşă̆ıdaki gibi tanımlanmaktadır: 
Sheker Sır, N., Karataş, H. ve Çeliköz, N. Education Sciences (NWSAES), 1C0645, 2015; 10(4): 237-252.

- Duyumsal (sensing) öğrenenler (somut, pratik, dikkat ve sabır gerektiren işlemleri, birbirine benzeyen işlemleri, laboratuar çalışmalarını, el uğraşılarını, problem çözmeyi tercih edenler, karmaşıklığı, sürprizi ve gerçek yaşamla uyumsuz bilgileri sevmeyenler) ve sezgisel (intuitive) öğrenenler (kavramsal, teorik bilgileri ve anlamları, yeni kavramları, hızlı çalışmayı, olasılıkları araştırmayı tercih edenler, tekrarı, matematiksel formülleri, soyut bilgileri ezberlemeyi ve rutin hesaplamaları sevmeyenler).

- Görsel (visual) öğrenenler (görsel sunumları ve resim, fotoğraf, şema, diyagram gibi görsel materyalleri tercih edenler) ve sözel (verbal) öğrenenler (yazılı ve sözlü açıklamaları tercih edenler).

- Aktif (active) öğrenenler (denemeyi, uygulamayı, tartışmayı, başkalarıyla çalışmayı, aktif olmayı tercih edenler, not tutmayı sevmeyenler) ve yansıtan (reflective) öğrenenler (öncelikle üstünde düşünmeyi, yalnız çalışmayı tercih edenler, başkalarıyla çalışmayı sevmeyenler) .

- Ardışık (sequential) öğrenenler (doğrusal, düzenli bilgileri, küçük adımlarla ilerlemeyi tercih edenler, bütünü sevmeyenler) ve bütünsel (global) öğrenenler (sistemsel, bütünsel düşünmeyi, bütünü kavramayı, büyük adımlarla ilerlemeyi tercih edenler, ayrıntıları sevmeyenler).

Bu amaçlar doğrultusunda, bu araştırma kapsamında (1) 'Müzik, Matematik, Türkçe, Beden Eğitimi ve Fen Bilgisi öğretmen adaylarının baskın öğrenme stilleri nelerdir?', (2) 'Öğretmen adaylarının öğrenme stilleri cinsiyete göre anlamlı farklılık göstermekte midir?', (3) 'Öğretmen adaylarının öğrenme stilleri bölümlere göre anlamlı farklılık göstermekte midir?', (4) 'Öğretmen adaylarının öğrenme stilleri sınıf düzeylerine göre anlamlı farklılık göstermekte midir?' sorularına yanıt aranmıştır.

\section{YÖNTEM (METHOD)}

\subsection{Araştırma Modeli (Research Model)}

Bu araştırmanın yürütülmesinde genel tarama modeli kullanılmıştır. Bilindiği gibi tarama modelleri, geçmişte ya da halen var olan bir durumu var olduğu şekliyle betimlemeyi amaçlayan araştırma yaklaşımlarıdır. Araştırmaya konu olan olay, birey ya da nesne, kendi koşulları içinde ve olduğu gibi tanımlanmaya çalışılır. Onları herhangi bir şekilde etkileme ya da değiştirme çabası yoktur. Önemli olan var olanı var olduğu şekliyle betimleyebilmektir (Karasar, 2006). Türkçe, Fen Bilgisi, Müzik, Matematik ve Beden Eğitimi Öğretmenliği öğrencilerinin baskın öğrenme stillerinin, ölçeğe verilen yanıtların nicel analizi ile saptanması sebebiyle bu çalışma betimsel (Fer, 2003) nitelikli bir çalışmadır. Bununla birlikte, bu araştırma çerçevesinde çok sayıda elemandan oluşan bir evrende, evren hakkında genel bir yargıya varmak için evrenden alınan bir örnek üzerinde inceleme yapılması nedeniyle tarama modeli (Ekici ve Havedanlı, 2010) kullanılmıştır.

\section{2. Çalışma Grubu (Study Group)}

Çalışma evreni Eğitim Fakültelerinde okuyan öğretmen adayı öğrencilerden oluşurken, çalışmanın örneklemi olarak Marmara Üniversitesi, Maltepe Üniversitesi ve Yıldız Teknik Üniversitesi'nde okuyan toplam 590 öğrenciden oluşmaktadır. Çalışma evreninde yer alan öğretmen adaylarının sayıca fazla olması, zaman, maliyet, ulaşım vb. problemler dikkate alınarak, araştırma için bir örneklem seçimine gidilmiştir Araştırmanın gerçekleştirildiği okullar ve bölümler 
Seker Sır, N., Karataş, H. ve Çeliköz, N. Education Sciences (NWSAES), 1C0645, 2015; 10(4): 237-252.

\begin{tabular}{llll}
\hline \hline kolayda örnekleme (convenience & sampling) yöntemiyle seçilirken \\
katılımcıların bölüm ve sınıf & düzeyi bazında homojen olarak \\
dağılmasına özen gösterilmiştir. & & &
\end{tabular}

Tablo 1. Öğretmen adaylarının cinsiyet ve bölüm değişkenlerine göre dağılımları

(Table 1. Distribution of pre-service teachers in terms of gender and departments)

\begin{tabular}{|c|c|c|c|c|c|c|c|c|}
\hline \multicolumn{2}{|c|}{} & \multicolumn{5}{c|}{ Bölüm } & \multicolumn{2}{c|}{ Toplam } \\
\cline { 3 - 9 } \multicolumn{2}{|c|}{ Cinsiyet } & Beden & Fen & Matematik & Müzik & Türkçe & Frekans & $\%$ \\
\cline { 2 - 8 } & Kız & 55 & 21 & 24 & 32 & 62 & 194 & 33 \\
\hline \multicolumn{2}{|c|}{ Toplam } & 34 & 94 & 73 & 68 & 127 & 396 & 67 \\
\hline
\end{tabular}

Tablo 1'de görüldüğü üzere, araştırmaya 55'i Beden Eğitimi, 21'i Fen Bilgisi, 24'ü Matematik, 32'si Müzik ve 62'si Türkçe olmak üzere 194 (33) erkek öğrenci; 34'ü Beden Eğitimi, 94'ü Fen Bilgisi, 73'ü Matematik, 68'i Müzik ve 127'si Türkçe olmak üzere 396 (\%67) kız öğrenciden oluşan toplam 590 öğrenci araştırmaya katılmıştır. Örneklemin o15'ini Beden Eğitimi, 20'sini Fen Bilgisi, 16'sını Matematik, ஃ17'sini Müzik, o32'sini ise Türkçe Öğretmenliği bölümünde okuyan öğrenciler oluşturmaktadır.

Tablo 2. Öğretmen adaylarının cinsiyet ve sınıf değişkenlerine göre dağılımları

(Table 2. Distribution of pre-service teachers in terms of gender and grades)

\begin{tabular}{|c|c|c|c|c|c|c|}
\hline \multicolumn{2}{|c|}{} & \multicolumn{4}{|c|}{ Sınıf } & \multirow{2}{*}{ Düzeyi } \\
\cline { 3 - 6 } \multicolumn{2}{|c|}{ Cinsiyet } & 1 & 2 & 3 & 4 & \\
\cline { 2 - 6 } & Erkek & 49 & 46 & 40 & 59 & 194 \\
\hline \multicolumn{2}{|c|}{ Toplam } & 104 & 118 & 67 & 107 & 396 \\
\hline \multicolumn{2}{|c|}{} & 89 & 153 & 164 & 107 & 166 \\
\hline
\end{tabular}

Tablo 2'de gösterildiği gibi katılımcıların sınıf düzeyi bazında dağılımına bakıldığında, 153 öğrencinin (26) birinci sınıf, 164 öğrencinin (잉) ikinci sınıf, 107 öğrencinin (18) üçüncü sınıf ve 166 öğrencinin (\%28) dördüncü sınıfta öğrenim gördüğü görülmektedir.

\subsection{Veri Toplama Aracı (Data Collecting Instrument)}

Bu araştırmada, öğretmen adaylarının baskın öğrenme stillerinin belirlenmesi amacıyla Felder ve Silverman (1996) tarafından geliştirilen ve Fer (2003) tarafından Türkçeye uyarlanan Öğrenme stilleri Envanteri kullanılmıştır. Duyumsal/sezgisel, görsel/sözel, aktif/yansıtan ve ardışık/bütünsel olmak üzere katılımcıların öğrenme stilini (4) boyutta tanımlayan envanter, dört boyutlu öğrenme stilinin her birini 11'er madde ile ölçmeye çalışmaktadır. İkişer seçenekten oluşan her bir maddeye verilen cevaplar, katılımcının öğrenme stilinin söz konusu boyutunu etkilemektedir. Örneğin, duyumsal/sezgisel puanı ölçen 11 adet sorunun tamamında "a" seçeneğini işaretleyen bir katılımcının söz konusu boyuttaki puanı -11, tamamında "b" seçeneğini işaretleyen katılımcı ise +11 puan alacaktır. Örnek olarak, katılımcının puanının negatif olması onun söz konusu boyutta duyumsal, pozitif olması ise sezgisel olduğunu göstermektedir. Kullanılan ölçeğin güvenirlik testi SPSS-17 programı vasıtasıyla gerçekleştirilmiş ve maddelerin iç tutarlılığına (internal consistency) yönelik Cronbach Alpha katsayısının .59 olduğu belirlenmiştir. Söz konusu değerin 0.6'dan düşük olması sebebiyle ölçeğin güvenirliğinin görece düşük olduğu düşünülse de, Fer (2003)'ün de belirttiği gibi, zıt kutuplu ölçeklerin iç tutarlılığının çok 
seçenekli ölçeklere göre düşük çıktığı bilinmektedir (Akt. Zwanenberg, Wilkinson \& Anderson, 2000). Buna rağmen, ölçeğin kullanılmasının nedeni, öğrenme biçemlerini ölçen ölçeklerin genelde güvenirliğinin ve geçerliğinin düşük çıkmasıdır (DeBello, 1990; Zwanenberg, Wilkinson ve Anderson, 2000). Fer (2003) tarafından yürütülen ölçeğin geçerlilik çalışması ise faktör analizi yardımıyla yapılmıştır. Ölçeğin tüm varyansının 55'ini 16 adet faktör oluşturmaktadır. Örneğin görsel/sözel boyutu ölçen maddelerin 9 adedinin 2. ve 3. faktörlerde yer alması ve bu faktörlerin başka hiçbir maddeyi kapsamaması, görsel/sözel maddelerinin benzer nitelikleri ölçtüğünün bir göstergesi olarak değerlendirilebilir. Benzer şekilde, 2. ve 11. faktörler sadece duyumsal/sezgisel boyutu, 4., 5., 10. ve 13. faktörler sadece aktif/yansıtan boyutu, 6., 9., ve 15. faktörler ise sadece ardışık bütünsel boyutu ölçmektedir.

\section{BULGULAR VE TARTIŞMALAR (FINDINGS AND DISCUSSIONS)}

Bu bölüme öğretmen adaylarının öğrenme stillerinin dağılımlarının incelenmesi ile başlanmış ve ardından araştırmada yanıt aranan sorulara yönelik gerçekleştirilen analizlere ait bulgulara yer verilmiştir. Araştırmada ilk olarak bağımlı değişken olarak belirlenen öğrenme stili değişkeni boyutları açısından incelenmiştir. Çalışmada bağımlı değişkenler olarak kabul edilen öğrenme stili boyutlarının dağılımlarına Şekil 1'dekihistogramlarda yer verilmiştir.
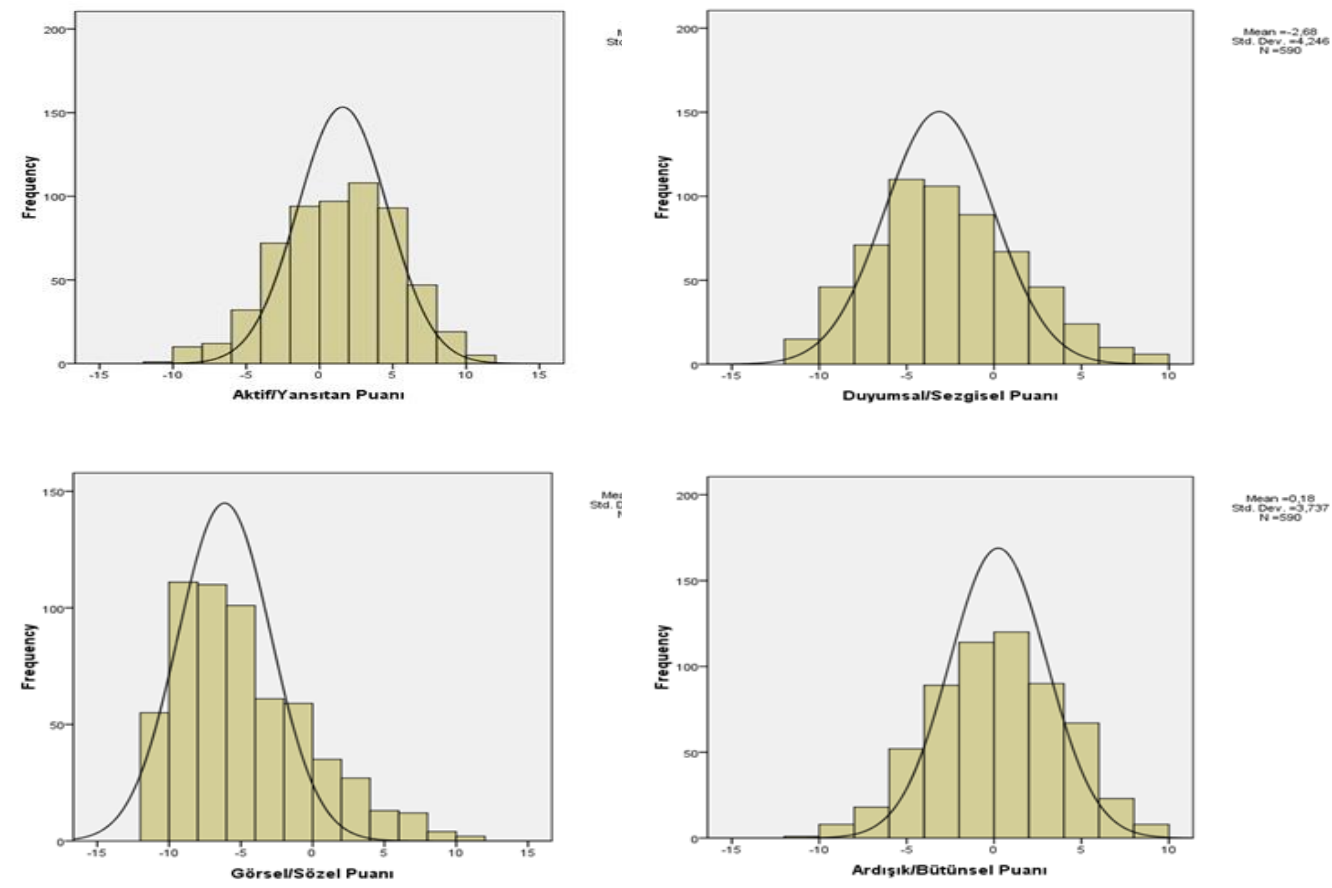

Şekil 1. Öğretmen adaylarının öğrenme stilleri ve boyutlarına ilişkin dağılım histogramı

(Figure 1. Distribution histogram of pre-service teachers in terms of their learning styles and dimensions)

Şekil 1'de de görüldüğü gibi, öğretmen adaylarının ortalama aktif/yansıtan puanları sıfırdan büyüktür. Bu durum, öğrencilerin söz konusu boyutta genellikle yansıtan özellik gösterdiklerini ifade etmektedir. Ortalama duyumsal/sezgisel ve görsel sözel puanları ise negatif değer aldıklarından katılımcıların genelinin duyumsal ve görsel oldukları söylenebilir. 
Sheker Sır, N., Karataş, H. ve Çeliköz, N. Education Sciences (NWSAES), 1C0645, 2015; 10(4):237-252.

Ardışık/bütünsel boyutta ise öğrencilerin daha dengeli bir
dağılım sergiledikleri görülmektedir. ör Tablo 3'de, ögretmen
adaylarının ölçeğin alt boyutlarından aldıkları puanların
dağılımlarına ilişkin kolmogorow-Smirnov Normallik Testi sonuçları
verilmiştir.

Tablo 3. Öğrenme stilleri değişkenlerine ilişkin kolmogorov-smirnov normallik dağılım testi

(Table 3. Normal distribution test of kolmogorov-smirnov relating to the variables of learning styles)

\begin{tabular}{|l|c|c|c|}
\hline \multirow{2}{*}{} & \multicolumn{3}{|c|}{ Kolmogorov-Smirnov ${ }^{\mathrm{a}}$} \\
\cline { 2 - 4 } & $\mathrm{n}$ & $\mathrm{t}$ & $\mathrm{p}$ \\
\hline Aktif/Yansıtan Puanı & 590 & $.11^{\star}$ & .00 \\
\hline Duyumsal/Sezgisel Puanı & 590 & $.11^{\star}$ & .00 \\
\hline Görsel/Sözel Puanı & 590 & $.16^{\star}$ & .00 \\
\hline Ardışık/Bütünsel Puanı & 590 & $.10^{\star}$ & .00 \\
\hline
\end{tabular}

$\star \mathrm{p}>.05$

Tablo 3'de de görüldüğü gibi, öğretmen adaylarının ölçeğin alt boyutlarından aldıkları puanların dağılımları Kolmogorov-Smirnov Normallik Testi ile incelenmiş ve normallik dağılımı varsayımının tüm alt boyutlar için sağlandığı bulunmuştur (p>.05). Öğretmen adaylarının cinsiyetlerinin onların baskın öğrenme stillerine olan etkileri, ttesti ile analiz edilmiştir. Tablo 4'de görüldüğü üzere kadın ve erkeklerin öğrenme stili boyutlarından aldıkları puanlar incelendiğinde sadece duyumsal/sezgisel boyuttan aldıkları puanlar arasında anlamlı bir fark olduğu görülmektedir (t=2.25, p<.05) .

Tablo 4. Öğretmen adaylarının öğrenme stillerinin cinsiyet değişkenine göre t-test analizi

(Table 4. T-test analysis of pre-service teachers' learning styles in terms of gender)

\begin{tabular}{|c|c|c|c|c|c|c|c|}
\hline Öğrenme stili & Cinsiyet & $\mathrm{N}$ & Ort. & Std. D. & Std. E. & $t$ & $\mathrm{p}$ \\
\hline \multirow{2}{*}{ Aktif/Yansıtan } & Kadın & 396 & 1.49 & 3.91 & .19 & \multirow{2}{*}{$-1 \cdot 38$} & \multirow{2}{*}{.16} \\
\hline & Erkek & 194 & 1.00 & 4.41 & .31 & & \\
\hline \multirow{2}{*}{ Duyumsal/Sezgisel } & Kadın & 396 & -2.96 & 4.11 & .20 & \multirow{2}{*}{2.25} & \multirow{2}{*}{$.02 \star$} \\
\hline & Erkek & 194 & -2.12 & 4.46 & .32 & & \\
\hline \multirow{2}{*}{ Görsel/Sözel } & Kadın & 396 & -4.56 & 4.72 & .23 & \multirow{2}{*}{$-1 \cdot 36$} & \multirow{2}{*}{.17} \\
\hline & Erkek & 194 & -5.11 & 4.43 & .31 & & \\
\hline \multirow{2}{*}{ Ardışık/Bütünsel } & Kadın & 396 & .05 & 3.72 & .18 & \multirow{2}{*}{1.23} & \multirow{2}{*}{.21} \\
\hline & Erkek & 194 & .45 & 3.75 & .27 & & \\
\hline
\end{tabular}

* $\mathrm{p}<0.5$

Tablo 4'deki bulgulara göre, her iki cinsin duyumsal/sezgisel puanının duyumsal lehine baskın olduğu ve kadınların bu boyuttan aldıkları puanların erkeklerin aldıkları puanlarla kıyaslandığında kadınlar lehine anlamlı bir farklılık gösterdiği görülmektedir. Bu sonuca göre, kadınların erkeklere nazaran biraz daha duyumsal olduğu görülmektedir. Öğretmen adaylarının okumakta oldukları bölümler ve onların baskın öğrenme stillerine ilişkin betimsel analiz sonuçları Tablo 5'de verilmiştir. 
Sheker Sır, N., Karataş, H. ve Çeliköz, N. Education Sciences (NWSAES), 1C0645, 2015; 10(4):237-252.

\begin{tabular}{|c|c|c|c|c|c|}
\hline \multicolumn{6}{|c|}{$\begin{array}{r}\text { Tablo 5. Öğretmen adaylarının öğrenme stilleri ve } \\
\text { ilişin betimsel istatistikler } \\
\text { (Tablo 5. Descriptive statistics of pre-service } \\
\text { styles and departments) }\end{array}$} \\
\hline & & $\mathrm{N}$ & Ort. & std. S. & Std. H. \\
\hline \multirow{6}{*}{ Aktif/Yansıtan Puanı } & Beden & 89 & -.46 & 4.46 & .47 \\
\hline & Fen & 115 & 1.38 & 3.68 & .34 \\
\hline & Matematik & 97 & 1.04 & 4.19 & .42 \\
\hline & Müzik & 100 & .88 & 4.16 & .41 \\
\hline & Türkçe & 189 & 2.53 & 3.68 & .26 \\
\hline & Toplam & 590 & 1.33 & 4.09 & .16 \\
\hline \multirow{6}{*}{ Duyumsal/Sezgisel Puanl } & Beden & 89 & -2.21 & 4.29 & .45 \\
\hline & Fen & 115 & -3.26 & 3.97 & .37 \\
\hline & Matematik & 97 & -3.19 & 4.13 & .42 \\
\hline & Müzik & 100 & -1.08 & 3.86 & .38 \\
\hline & Türkçe & 189 & -3.15 & 4.43 & .32 \\
\hline & Toplam & 590 & -2.68 & 4.24 & .17 \\
\hline \multirow{6}{*}{ Görsel/Sözel Puanı } & Beden & 89 & -5.94 & 3.89 & .41 \\
\hline & Fen & 115 & -5.57 & 4.05 & .37 \\
\hline & Matematik & 97 & -6.65 & 3.81 & .38 \\
\hline & Müzik & 100 & -4.12 & 4.40 & .44 \\
\hline & Türkçe & 189 & -3.02 & 5.13 & .37 \\
\hline & Toplam & 590 & -4.74 & 4.63 & .19 \\
\hline \multirow{6}{*}{ Ardışık/Bütünsel Puanı } & Beden & 89 & -.17 & 3.64 & .38 \\
\hline & Fen & 115 & -.74 & 3.70 & .34 \\
\hline & Matematik & 97 & -.32 & 3.46 & .35 \\
\hline & Müzik & 100 & .10 & 3.90 & .39 \\
\hline & Türkçe & 189 & 1.21 & 3.64 & .26 \\
\hline & Toplam & 590 & .18 & 3.73 & .15 \\
\hline
\end{tabular}

Tablo 5'deki bulgulara göre, Türkçe öğretmeni adayları ( $\bar{X}=2.53)$ diğer gruplara göre daha baskın yansıtan özelliği gösterirken Beden Eğitimi öğretmen adayları $(\bar{X}=-2.21)$ ise diğer tüm grupların aksine aktif tarafta çıkmıştır. Tüm grupların duyumsal ve görsel özellik gösterdiği, tüm gruplar arasında Fen Bilgisi öğretmen adaylarının en duyumsal ( $\bar{X}=-3.26)$, Matematik öğretmen adaylarının $(\bar{X}=-6.65)$ ise en görsel niteliğe sahip olduğu belirlenmiştir. Son olarak, Müzik $(\bar{X}=.10)$ ve Türkçe $(\bar{X}=1.21)$ öğretmen adayları diğer grupların aksine bütünsel özelliğe daha yatkındır.

Öğretmen adaylarının okumakta oldukları bölümlerin onların baskın öğrenme stillerine olan etkilerine ilişkin yapılan tek yönlü ANOVA analiz sonuçları Tablo 6'da verilmektedir. Tablo 6'da görüldüğü gibi, öğretmen adaylarının öğrenme stillerinin okudukları bölümlere göre anlamlı farklılıklar gösterdiği görülmektedir (Aktif/Yansıtan $\mathrm{F}=9.28, \mathrm{p}<.05$; Duyumsal/Sezgisel $\mathrm{F}=5.43, \mathrm{p}<.05 ;$ Görsel/Sözel F=14.74, $\mathrm{p}<.05$; Ardışık/Bütünsel $\mathrm{F}=6.18, \mathrm{p}<.05)$. Türkçe öğretmen adayları diğer gruplara göre daha baskın bir biçimde yansıtan öğrenme stilini sergilerken, Beden Eğitimi öğretmen adayları, diğer tüm grupların aksine aktif öğrenme stilini kullanmaktadırlar. 
Seker Sır, N., Karataş, H. ve Çeliköz, N. Education Sciences (NWSAES), 1C0645, 2015; 10(4): 237-252.

Tablo 6. Öğretmen adaylarının bölümlerine göre öğrenme stillerinin karşılaştırılmasına ilişkin tek yönlü ANOVA analizi sonuçları

(Table 6. ANOVA analysis relating topre-service teachers' learning styles in terms of departments)

\begin{tabular}{|c|l|c|c|c|c|c|}
\hline \multicolumn{2}{|c|}{} & $\begin{array}{c}\text { Kareler } \\
\text { Top. }\end{array}$ & Sd & $\begin{array}{c}\text { Kareler } \\
\text { Ort. }\end{array}$ & F & p \\
\hline \multirow{3}{*}{ Ardışık/Bütünsel } & Gruplar Arası & 588.18 & 4 & 147.04 & 9.28 & $.00 *$ \\
\cline { 2 - 7 } & Gruplar İçi & 9266.69 & 585 & 15.84 & & \\
\cline { 2 - 7 } & Toplam & 9854.88 & 589 & & & \\
\hline \multirow{3}{*}{ Aktif/Yansıtan } & Gruplar Arası & 380.37 & 4 & 95.09 & 5.43 & $.00 *$ \\
\cline { 2 - 7 } & Gruplar İçi & 10236.98 & 585 & 17.49 & & \\
\cline { 2 - 7 } & Toplam & 10617.36 & 589 & & & \\
\hline \multirow{3}{*}{ Duyumsal/Sezgisel } & Gruplar Arası & 1159.44 & 4 & 289.86 & 14.74 & $.00 *$ \\
\cline { 2 - 7 } & Gruplar İçi & 11497.39 & 585 & 19.65 & & \\
\cline { 2 - 7 } & Toplam & 12656.84 & 589 & & & \\
\hline & Gruplar Arası & 333.95 & 4 & 83.48 & 6.18 & .00 \\
\cline { 2 - 7 } & Gruplar İçi & 7892.27 & 585 & 13.49 & & \\
\cline { 2 - 7 } & Toplam & 8226.23 & 589 & & & \\
\hline
\end{tabular}

$\star \mathrm{p}<0.5$

Ayrıca tüm grupların duyumsal ve görsel öğrenme stiline sahip oldukları, tüm gruplar arasında Fen Bilgisi öğrenmen adaylarının duyumsal öğrenme stilini daha fazla kullandıkları, Matematik öğretmen adaylarının ise en çok görsel öğrenme stiline sahip oldukları belirlenmiştir. Son olarak, Müzik ve Türkçe öğretmen adayları diğer grupların aksine bütünsel öğrenme stiline daha yatkın görünmektedirler. Öğretmen adaylarının okumakta oldukları sınıflar ve onların baskın öğrenme stillerine ilişkin istatistiki bilgiler ve sınıf düzeyi değişkenine göre tek yönlü ANOVA analizi sonuçları Tablo 7 ve Tablo 8'de verilmiştir.

Tablo 7. Öğretmen adaylarının öğrenme stilleri ve sınıf değişkenlerine ilişkin betimsel istatistikler

(Table 7. Descriptive statistics of pre-service teachers' learnings tyles in terms of grades)

\begin{tabular}{|l|c|c|c|c|c|}
\hline \multirow{4}{*}{ Aktif/Yansıtan } & & $\mathrm{N}$ & Ortalama & Std. S. & Std. H. \\
\cline { 2 - 6 } & 1 & 153 & 1.88 & 3.77 & .30 \\
\cline { 2 - 6 } & 2 & 164 & 1.79 & 4.04 & .31 \\
\cline { 2 - 6 } & 3 & 107 & .94 & 4.17 & .40 \\
\cline { 2 - 6 } & Toplam & 590 & 1.33 & 4.09 & .16 \\
\hline Duyumsal/Sezgisel & 1 & 153 & -2.69 & 4.20 & .34 \\
\cline { 2 - 6 } & 2 & 164 & -2.98 & 4.50 & .35 \\
\cline { 2 - 6 } & 3 & 107 & -2.79 & 4.05 & .39 \\
\cline { 2 - 6 } & 4 & 166 & -2.33 & 4.15 & .32 \\
\cline { 2 - 6 } & Toplam & 590 & -2.68 & 4.24 & .17 \\
\hline Görsel/Sözel & 1 & 153 & -4.37 & 4.51 & .36 \\
\cline { 2 - 6 } & 2 & 164 & -3.84 & 4.79 & .37 \\
\cline { 2 - 6 } & 3 & 107 & -5.11 & 4.21 & .40 \\
\cline { 2 - 6 } & 4 & 166 & -5.73 & 4.66 & .36 \\
\cline { 2 - 6 } & Toplam & 590 & -4.74 & 4.63 & .19 \\
\cline { 2 - 6 } & 1 & 153 & -.16 & 3.80 & .30 \\
\cline { 2 - 6 } & 2 & 164 & .52 & 3.74 & .29 \\
\cline { 2 - 6 } & 3 & 107 & .42 & 3.70 & .35 \\
\cline { 2 - 6 } & 4 & 166 & .01 & 3.68 & .28 \\
\cline { 2 - 6 } & Toplam & 590 & .18 & 3.73 & .15 \\
\hline
\end{tabular}


Seker Sır, N., Karataş, H. ve Çeliköz, N. Education Sciences (NWSAES), 1C0645, 2015; 10(4): 237-252.

Tablo 8. Öğretmen adaylarının sınıflarına göre öğrenme stillerinin karşılaştırılmasına ilişkin tek yönlü ANOVA analizi sonuçları

(Table 8. ANOVA analysis relating to pre-service teachers' learning styles in terms of grades)

\begin{tabular}{|c|c|c|c|c|c|c|}
\hline & & $\begin{array}{c}\text { Kareler } \\
\text { Top. }\end{array}$ & $\mathrm{Sd}$ & $\begin{array}{c}\text { Kareler } \\
\text { Ort. }\end{array}$ & $\mathrm{F}$ & $\mathrm{p}$ \\
\hline \multirow[t]{3}{*}{ Aktif/Yansıtan } & Gruplar Arası & 178.78 & 3 & 59.59 & 3.60 & $.01 *$ \\
\hline & Gruplar İçi & 9676.09 & 586 & 16.51 & & \\
\hline & Toplam & 9854.88 & 589 & & & \\
\hline \multirow[t]{3}{*}{ Duyumsal/Sezgisel } & Gruplar Arası & 36.60 & 3 & 12.20 & .67 & .56 \\
\hline & Gruplar İçi & 10580.75 & 586 & 18.05 & & \\
\hline & Toplam & 10617.36 & 589 & & & \\
\hline \multirow[t]{3}{*}{ Görsel/Sözel } & Gruplar Arası & 332.20 & 3 & 110.73 & 5.26 & $.00 *$ \\
\hline & Gruplar $\dot{I} c ̧ i$ & 12324.63 & 586 & 21.03 & & \\
\hline & Toplam & 12656.84 & 589 & & & \\
\hline \multirow[t]{3}{*}{ Ardışık/Bütünsel } & Gruplar Arası & 48.36 & 3 & 16.12 & 1.15 & .32 \\
\hline & Gruplar $\dot{I} c ̧ i$ & 8177.86 & 586 & 13.95 & & \\
\hline & Toplam & 8226.23 & 589 & & & \\
\hline
\end{tabular}

Sınıf düzeyi değişkeninin öğrenme stillerinin aktif/yansıtan $(\mathrm{F}=3.60, \mathrm{p}<.05)$ ve görsel/sözel $(\mathrm{F}=5.26, \mathrm{p}<.05)$ boyutlarında anlamlı farklılıklar oluşturduğu görülmektedir. Öğretmen adaylarının okudukları sınıf düzeyi ilerledikçe aktif/yansıtan boyutu yansıtan özellik göstermeye devam etmekle birlikte aktif boyuta yaklaşmaktadır. Görsel/sözel boyutta ise genel olarak sınıf düzeyi ilerledikçe görsel özelliğin arttı ğı belirlenmiştir.

\section{SONUÇ VE ÖNERILER (CONCLUSION AND RECOMMENDATIONS)}

Bu bölümde, öğretmen adaylarının öğrenme stilleri boyutları ve bu boyutların cinsiyet, bölüm ve sınıf değişkenlerine göre incelenmesine ilişkin oluşturulan araştırma sorularına yönelik ulaşılan bulgular tartışılmıştır.

590 öğretmen adayı üzerinde yapılan araştırma neticesinde katılımcıların yansıtan, duyumsal, görsel ve bütünsel öğrenme stillerinde yoğunlaştıkları gözlenmiştir. Bu sonuç, Fer (2003) tarafından gerçekleştirilen araştırma sonucu ile uyumludur. Cinsiyet değişkeninin Felder ve Silverman modeline göre sadece duyumsal/sezgisel boyutta etkili olduğu, her iki cinsin tercihinde sezgisel olduğu ancak kadınların erkeklere nazaran daha çok sezgisel özellik gösterdiği görülmüştür. Bu bulgudan hareketle, cinsiyetin öğrenme stili tercihleri üzerinde görece fazla bir etkisinin bulunmadığı sonucuna ulaşılabilir. Söz konusu bulgu, Fer (2003)'ün Matematik, Fizik ve Kimya bölümlerinde okuyan 106 öğrenci üzerinde Felder ve Silverman ölçeğini kullanarak gerçekleştirdiği araştırma sonuçları ile örtüşmektedir. Ayrıca, Köse (2010), Deniz ve ark. (2008), Sünbül ve Yağışan (2009), Gürsoy (2008), Çöğenli (2011), Bahar (2011) ve Demir (2008)'in, cinsiyetin öğrenme stillerini anlamlı olarak etkilemediği sonucuna ulaştıkları araştırmalar ile benzer sonuçlara ulaşılmıştır.

Araştırmada öğretmen adayı öğrencilerin okudukları bölümlerin onların öğrenme stillerini etkilediği, Felder ve Silverman modeline göre incelenen dört boyuta ait puanların da eğitim görülen bölüme göre anlamlı olarak değiştiği sonucuna ulaşılmıştır. Bu sonuç, Deniz ve ark. (2008), Sünbül ve Yağışan (2009) ve Gürsoy (2008)'in bulguları ile benzerlik göstermekle birlikte, Bahar, Gülaçtı ve Özen (2009)'un Eğitim Fakültesi öğrencileri, Genç ve Kocaarslan (2013) ile Alşahan ve Zengin (2010)'un Fen, Sosyal Bilgiler ve Sınıf öğretmen adayları 
Sheker Sır, N., Karataş, H. ve Çeliköz, N. Education Sciences (NWSAES), 1C0645, 2015; 10(4): 237-252.

üzerinde Kolb öğrenme modeline göre gerçekleştirdikleri araştırma sonuçları ile farklılık arz etmektedir.

Eğitim görülen bölümün öğrenme stillerine olan etkisinin incelenmesi neticesinde, sadece Benden Eğitimi öğretmen adaylarının aktif öğrenme stiline sahip olduğu, en yansıtan özelliği gösterenlerin ise Türkçe öğretmen adayları olduğugörülmüştür. Katılımcıların tamamı duyumsal özellik gösterirken, en duyumsal olanlar Fen Bilgisi öğretmen adayları, en az duyumsal özellik gösterenler ise Müzik öğretmen adaylarıdır. Öğrencilerin tamamı görsel öğrenme stiline sahipken, Matematik ve Türkçe öğretmen adayları sırasıyla en görsel ve en az görsel özellik gösterenler olarak ortaya çıkmaktadır. Fen Bilgisi öğretmen adayları en ardışık özelliğe sahipken Türkçe öğretmen adayları ise en bütünsel grup olarak belirmektedir.

Sınıf düzeyinin öğrenme stilleri üzerinde sınırlı seviyede etkili olduğu görülmüştür. Sınıf düzeyi katılımcıların aktif/yansıtan ve görsel/sözel puanları üzerinde etkilidir. Köprülü (2004)'ün Felder ve Silverman ölçeğini kullandığı araştırmasında de benzer şekilde sınıf düzeyinin öğrenme stili tercihini anlamlı olarak etkilediği sonucuna ulaşılmıştır. Öte yandan, Kolb öğrenme stili envanterinin kullanıldığı Koç (2010), Erişti ve Yalız (2010) ve Deniz (2011)'de sınıf düzeyinin öğrenme stili tercihlerini etkilemediği ifade edilmektedir. Eğitim görülen sınıf düzeyinin öğrenme stillerine olan etkisinin incelenmesi neticesinde, sınıf düzeyi ilerledikçe katılımcıların yansıtan özelliklerinin azaldığı, görsel özelliklerinin ise arttığı sonucuna ulaşılmıştır.

Öğretmen adaylarının öğrenme stilleri boyutlarına ilişkin yapılan araştırmalar sonucunda öğretmen adaylarının farklı öğrenme stilleri boyutlarında baskın oldukları gözlemlenmiştir. Bu durum, öğretmen adayı bakış açısıyla öğrenme ortamlarının hazırlanmasında farklı öğrenme stillerine sahip öğrencilerin eğilimlerinin dikkate alınması gerektiğini ve bu eğilimlerin öğrenme sürecinde desteklenmesi gerektiğini ortaya çıkarmaktadır. Bundan sonra yapılacak olan araştırmalarda öğrenme stilleri ile öğretmen adaylarının kullandıkları öğretim stratejileri, yöntemleri ve teknikleri arasındaki ilişkinin incelenmesi alana büyük katkı yapacaktır.

Öğretmen adaylarının, mesleğe başlamadan önce öğrenme stillerinin ortaya çıkarılmasının onlara meslek yaşamlarında birçok yönden katkıda bulunabileceği söylenebilir. Kendi öğrenme stilini bilen öğretmen adayları daha sonra mesleğe başladıklarında öğrencilerinin öğrenme stillerine uygun öğrenme ortamı oluşturmaya dikkat edeceklerdir (Entwistle-McCune vd., 2001:85-113). Sonuç olarak, eğer bireylerin öğrenme stillerinin ne olduğu belirlenirse öğretmen öncelikle kendisi, sonra da öğrenciler için bu şartlara uygun öğrenme ve öğretme ortamları hazırlayabilir.

\section{NOT (NOTE)}

Bu çalışma, 01.03.2014 tarihinde İstanbulda düzenlenmiş olan YICER (YILDIZ International Conference on Educational Research and Social Sciences) konferansında sözlü bildirim olarak sunulmuştur.

\section{KAYNAKLAR (REFERENCES)}

- Aktepe, V., (2005). Eğitimde Bireyi Tanımanın Önemi. Gazi Üniversitesi Kırşehir Eğitim Fakültesi Dergisi, 6(2), 15-24.

- Alaçayır, S., (2011). Zihin Engelliler Öğretmenliği Bilim Dalı Zihin Engelliler Öğretmeni Adaylarının Yeterlik Algıları İle Öğrenme Stilleri Arasındaki İlişkinin İncelenmesi. Yüksek Lisans Tezi, Marmara Üniversitesi, İstanbul. 
Seker Sır, N., Karataş, H. ve Çeliköz, N. Education Sciences (NWSAES), 1C0645, 2015; 10(4): 237-252.

- Arslan, B. ve Babadoğan, C., (2005). İlköğretim 7. ve 8. Sınıf Öğrencilerinin Öğrenme Stillerinin Akademik Başarı Düzeyi, Cinsiyet ve Yaş İle İlişkisi. Eğitim Araştırmaları, 21, 35-48.

- Babadoğan, C., (2000). Öğretim Stili Odaklı Ders Tasarımı Geliştirme. Milli Eğitim Dergisi, Sayı:147, 61-63.

- Bahar, M. ve Bilgin, İ., (2008). Sınıf Öğretmenlerinin Öğretme ve Öğrenme Stilleri Arasındaki İlişkinin Incelenmesi, Gazi Eğitim Fakültesi Dergisi, 28(1), 19-38.

- Bahar, H.H. ve Sülün, A., (2011). Fen Bilgisi Öğretmen Adaylarının Öğrenme Stilleri, Cinsiyet Öğrenme Stili İlişkisi ve Öğrenme Stiline Göre Akademik Başarı, Kastamonu Eğitim Dergisi, $19(2), 379-386$.

- Bahar, H.H., Özen, Y. ve Gülaçtı, F., (2009). Eğitim Fakültesi Öğrencilerinin Cinsiyet ve Branşa Göre Akademik Başarı Durumları ile Öğrenme Stillerinin İncelenmesi, Ankara Üniversitesi Eğitim Bilimleri Fakültesi Dergisi, $42(1), 69-86$.

- Bilgin, İ. ve Durmuş, S., (2003). Öğrenme Stilleri ve Öğrenci Başarısı Arasındaki İlişki Üzerine Karşılaştırmalı Bir Araştırma. Kuram ve Uygulamada Eğitim Bilimleri, 3(2), 381-400.

- Biggs, J., (2001). "Enhacing Learning: A Matter of style or Approach (73-102)". In Perspectives on Thinking, Learning and Cognitive Styles. Mahwah: Lawrance Erlbaum Associates.

- Collison, E., (2000). A survey of Elementary Students Learning Style Preferences and Academic Success. Contemporary Education, $71,42-49$.

- Çiğdem, G., (2010). Sınıf Öğretmenliği Adaylarının Öğrenme Stilleri ve Öğretmenlik Mesleğine Yönelik Tutumlarının Çeşitli Değişkenler Açısından İncelenmesi. Yüksek Lisans Tezi, Karaelmas Üniversitesi, Zonguldak.

- De Bello, T., (1990). Comparison of eleven major learning styles models: Variables, appropriate populations, validity of instrumentation and there search behind them. Journal of Reading, Writing and Learning Disabilities International, 6(3), 203-222

- Demir, T., (2008). Türkçe Eğitimi Bölümü Öğrencilerinin Öğrenme Stilleri ve Bunların Çeşitli Değişkenlerle İlişkisi (Gazi Üniversitesi Örneği), Uluslararası Sosyal Araştırmalar Dergisi, $1(4), 129-148$.

- Deniz, J., (2011). Müzik Öğretmeni Adaylarının Öğrenme Stilleri, 2nd International Conference on New Trends in Education and Their Implications, Antalya.

- Deshields, B.E.W., (2005). Comparison of the Learning Styles of Nurses and Teachers in Bermuda By Age, Gender, Educational Level, And Professional Longevity, Doktora Tezi, St. John's University, New York.

- Ekici, G. ve Hevedanlı, M., (2010). Lise Öğrencilerinin Biyoloji Dersine Yönelik Tutumlarının Farklı Değişkenler Açısından Incelenmesi. Türk Fen Eğitimi Dergisi, 7(4), 97-109.

- Entwistle, N., Mccune, V. and Ealker, P., (2001). Conceptions, Styles and Approaches Within Higher Education: Analytic Abstractions and Everyday Experience (103-136). In Perspectives on Thinking, Learning and Cognitive Styles. Mahwah: Lawrance Erlbaum Associates.

- Felder, R.M., (1996). Matters of style. Asee Prism, 6(4), 18-23. 
Seker Sır, N., Karataş, H. ve Çeliköz, N. Education Sciences (NWSAES), 1C0645, 2015; 10(4): 237-252.

- Felder, R., and Spurlin, J., (2005). Applications, reliability, and validity of the index of learning styles. International Journal of Engineering Education, 21(1), 103-112.

- Fer, S., (2003). Matematik, Fizik ve Kimya Öğretmenliği Öğrencilerinin Öğrenme Biçemlerine Göre Kolay Öğrendikleri Öğrenme Etkinlikleri, Çă̆daş Eğitim, 28(304), 33-43.

- Genç, M. ve Kocaarslan, M., (2013). Öğretmen Adaylarının Öğrenme Stillerinin Çeşitli Değişkenler Açısından İncelenmesi: Bartın Üniversitesi Örneği, Türkiye Sosyal Araştırmalar Dergisi, $17(2)$, 327-344.

- Gündoğan Çögenli, A., (2011). Sınıf Öğretmenlerinin Sahip Oldukları Öğrenme Stilleri ve Kullandıkları Bilişüstü Öğrenme Stratejileri. Yüksek Lisans Tezi, Anadolu Üniversitesi, Eskişehir.

- Gürsoy, T., (2008). Öğretmen Adaylarının Öğrenme Stillerinin Çeşitli Değişkenler Açısından İncelenmesi. Yüksek Lisans Tezi, Adnan Menderes Üniversitesi, Aydın.

- Güven, B. and Özbek, Ö., (2007). Developing Learning Style Inventory for Effective Instructional Design, The Turkish Online Journal of Educational Technology-TOJET, 6(2).

- Hawk, T.F., and Shah, A.J., (2007). Using learning style instruments to enhance student learning. Decision Sciences Journal of Innovative Education, 5(1), 1-19.

- Hein, T.L. and Budny, D.D., (2000). Styles and Types in Scienceand Engineering Education. Paper Presented International Conference on Engineering and Computer Education, San Paulo, Brazil.

- Karasar, N., (2006). Bilimsel Araştırma Yöntemleri. Ankara: Nobel Yayın Dağıtım.

- Keleş, D., (2009). Öğretmen Adaylarının Alan Eğitimi ve Bazı Psiko-sosyal Değişkenlere Göre Denetim Odağı Eğilimleri İle Öğrenme Stilleri Tercihleri. Yüksek Lisans Tezi, Pamukkale Üniversitesi, Denizli.

- Koç, D., (2010). Beden Eğitimi ve Spor Yüksekokulu Öğrencilerinin Öğrenme Stillerinin İncelenmesi ve Belirlenmesi. Yüksek Lisans Tezi, Marmara Üniversitesi, İstanbul.

- Köprülü, Ö., (2004). Learning Styles of Student-Teachers in English Language Departments in Some Faculties of Education with Respect to Foreign Language Learning and Teaching. Doktora Tezi, Dokuz Eylül Üniversitesi, İzmir.

- Köse, A., (2010). Fen Bilgisi Öğretmen Adaylarının Öğrenme Stilleri, Ders Çalışma Stratejileri ile Fen Bilgisi Öğretimi Öz Yeterlik İnançları Arasındaki İlişki (ÇOMÜ Örneği). Yüksek Lisans Tezi, Onsekiz Mart Üniversitesi, Çanakkale.

- Küçükkaragöz, H., Deniş H., Ersoy, E. ve Karataş, E.,(2009). İlköğretim Matematik, Fen Bilgisi ve Türkçe Öğretmen Adaylarının Öğrenme Stilleri ve Problem Çözme Becerilerinin İncelenmesi. I. Uluslararası Türkiye Eğitim Araştırmaları Kongresi, Çanakkale.

- Ömeroğlu, Ö., (2008). Yeni Bir İnsan Hakkı: Benzersiz Olma Hakkı, Dokuz Eylül Üniversitesi Hukuk Fakültesi Dergisi, $10(2)$, 99-132.

- Peker, M., (2003). Öğrenme Stilleri ve 4 MAT Yönteminin Öğrencilerin Matematik Tutum ve Başarılarına Etkisi, Yayınlanmamış Doktora Tezi. Gazi Üniversitesi Eğitim Bilimleri Enstitüsü, Ankara. 
- Scales, A.Y., (2000). The Effect of Learning Style, Major and Gender on Learning Computer-aided Drawing in an Introductory Engineering/Technical Graphics Course. Unpublished PhD Thesis, North Carolina State University.

- Öğrenme Stilleri ile Fen ve Teknoloji Öğretimi Dersindeki Akademik Başarıları Arasındaki İlişki. Yüksek Lisans Tezi, Pamukkale Üniversitesi, Denizli.

- Sywelem, M., Dahawy, B., and Wang, C., (2010). An Examination of Learning Style Preferences Among Egyptian University Students, Institute for Learning Styles Journal, 1, 16-23.

- Şimşek, N., (2001), Öğretim Teknolojilerinin Özellikleri ve Kullanımı. Öğretim Teknolojileri ve Kullanımı Kursu Ders Notları. Ankara, Emniyet Genel Müdürlüğü Basım Evi.

- Tseng, S., (2001). Nontradition Taiwanese EFL Students Learning Style Preferences, PhD Thesis, University of South Dakota, ABD.

- Uzuntiryaki, E., Bilgin, İ ve Geban, Ö., (2002). The Effect of earning Styles on High School Students' Achievement and Attitudes in Chemistry. Paper presented at the Annual Meeting of the National Association for Research in Science Teaching, Philadelphia, PA, (ERIC Document Reproduction Service No.ED (475-483).

- Van Zwanenberg, N., Wilkinson, L.J., and Anderson, A., (2000). Felder and Silverman's Index of Learning Styles and Honey and Mumford's Learning Styles Questionnaire: how dothey compare and do they predict academic performance? Educational Psychology, $20(3), 365-380$.

- Yağışan, N. ve Sünbül, A.M., (2009). Güzel Sanatlar Eğitimi Bölümü Öğrencilerinin Öğrenme Tercihleri, 8. Ulusal Müzik Eğitimi Sempozyumu, Samsun.

- Yalız, D. ve Erişti, B., (2009). Anadolu Üniversitesi Beden Eğitimi ve Spor Öğretmenliği Bölümü Öğrencilerinin Öğrenme Stilleri, Beden Eğitimi ve Spor Bilimleri Dergisi, 4(4), 156163.

- Yenice, N. ve Saracaloğlu, A.S., (2009). Sınıf Öğretmeni Adaylarının Öğrenme Stilleri ile Fen Başarıları Arasındaki İlişki, Yüzüncü Yıl Üniversitesi Eğitim Fakültesi Dergisi, 4(1), $162-173$.

- Zengin, R. ve Alşahan Ö.L., (2011). İlköğretim Öğretmen Adaylarının Öğrenme Stillerinin İncelenmesi, Erzincan Üniversitesi Eğitim Fakültesi Dergisi, 13(2), 143-153. 